BIODIK: Jurnal IImiah Pendidikan Biologi
ISSN 2580-0922 (online), ISSN 2460-2612 (print)
Volume 6, Nomor 04, Tahun 2020, Hal. 519-525
Available online at:
https://online-journal.unja.ac.id/biodik

Research Article

open ACCESS

\title{
Profil Keterampilan Proses Sains Siswa Kelas VII SMP Pada Materi Ekosistem
}

\section{(Profile of Science Process Skills Class VII Junior High School Students in Ecosystem Material)}

Lu'lu Robiatul F.N.*, Setiono, Suhendar

Universitas Muhammadiyah Sukabumi

Jalan R. Syamsudin SH No. 50 Kec. Cikole Kota Sukabumi-Indonesia

*Corresponding author: lulurobiatulfajin@gmail.com

\begin{tabular}{|c|c|}
\hline Informasi Artikel & ABSTRACT \\
\hline $\begin{array}{l}\text { Submit: } 19-08-2020 \\
\text { Diterima: } 10-11-2020 \\
\text { Dipublikasikan: } 18-12-2020\end{array}$ & $\begin{array}{l}\text { The research aims to determine the profile of science process skills and concept } \\
\text { mastery of class VII students of SMP Negeri Sukabumi. This research was conducted } \\
\text { in April 4th week at one of the SMP Negeri Sukabumi City. This research uses a } \\
\text { descriptive method. The approach used in this study is a qualitative approach. The } \\
\text { population used in this study were } 30 \text { students of class VII SMP Negeri Kota } \\
\text { Sukabumi. Sampling of data in this study is by using purposive sampling technique. } \\
\text { The data was collected by using a written test in the form of multiple choice questions } \\
\text { of science process skills, amounting to } 20 \text { questions with a reliability of } 0.88 \text { with a } \\
\text { standard deviation of } 3.20 \text { and a correlation of } 0.63 \text { using } 10 \text { indicators of science } \\
\text { process skills. The results showed that the profile of the science process skills of } \\
\text { students of class VII SMP Negeri Kota Sukabumi in the } 2019 / 2020 \text { school year was } \\
\text { still in the low category. However, from these results, science process skills can still } \\
\text { be trained and improved through the use of learning models, strategies and } \\
\text { approaches that are able to stimulate the science process skills of students. } \\
\text { Keywords: Science Process Skills, ecosystem, SMP }\end{array}$ \\
\hline Penerbit & ABSTRAK \\
\hline $\begin{array}{l}\text { Program Studi Pendidikan } \\
\text { Biologi, Fakultas Keguruan dan } \\
\text { IImu Pendidikan, Universitas } \\
\text { Jambi-Indonesia }\end{array}$ & $\begin{array}{l}\text { Penelitian ini bertujuan untuk mengetahui profil keterampilan proses sains dan } \\
\text { penguasaan konsep siswa kelas VII SMP Negeri Kota Sukabumi. Penelitian ini } \\
\text { dilaksanakan pada bulan april minggu ke- } 4 \text { di salah satu SMP Negeri Kota } \\
\text { Sukabumi. Penelitian ini menggunakan metode deskriptif. Pendekatan yang } \\
\text { digunakan dalam penelitian ini adalah pendekatan kualitatif. Populasi yang } \\
\text { digunakan dalam penelitian ini adalah siswa kelas VII SMP Negeri Kota Sukabumi } \\
\text { sebanyak } 30 \text { siswa. Pengambilan sampel data dalam penelitian ini yaitu dengan } \\
\text { menggunakan teknik purposive sampling. Pengumpulan data dilakukan dengan } \\
\text { menggunakan tes tertulis dalam bentuk pertanyaan soal pilihan ganda keterampilan } \\
\text { proses sains yang berjumlah } 20 \text { soal pertanyaan dengan reliabilitas } 0 \text {, } 78 \text { standar } \\
\text { deviasi } 3,20 \text { dan korelasi } 0,63 \text { menggunakan } 10 \text { indikator keterampilan proses sains. } \\
\text { Hasil penelitian menunjukkan bahwa profil keterampilan proses sains siswa peserta } \\
\text { didik kelas VII SMPN Kota Sukabumi pada tahun ajaran } 2019 / 2020 \text { masih dalam } \\
\text { kategori kurang. Namun dari hasil tersebut, keterampilan proses sains masih bisa } \\
\text { dilatihkan dan ditingkatkan melalui penggunaan model, strategi dan pendekatan } \\
\text { pembelajaran yang mampu merangsang keterampilan proses sains peserta didik. } \\
\text { Katakunci: Keterampilan Proses Sains, ekosistem, SMP }\end{array}$ \\
\hline
\end{tabular}




\section{PENDAHULUAN}

Karakteristik satuan pendidikan di Indonesia menuntut peserta didik untuk menggunakan pengetahuannya dan mampu mengidentifikasi masalah dalam pembelajaran maupun aplikasi kehidupan sehari-hari. Hal ini dapat terlaksana dengan baik apabila peserta didik memahami sains dengan baik. Pembelajaran sains saat ini dapat dikatakan masih belum maksimal dalam menerapkan kurikulum 2013.

Pembelajaran sains merupakan proses pembelajaran yang menuntut peserta didik mampu menemukan sesuatu dan dapat membangun pengetahuannya sendiri (kontruktivis) melalui metode ilmiah sehingga mendapatkan pengalaman secara langsung dengan pembelajaran bermakna untuk mengembangkan kompentensi yang dimiliki peserta didik. Joyce, et al. (2009) menyatakan bahwa pemahaman materi sains hanya bisa diperoleh apabila proses dalam sains dapat dipahami oleh peserta didik. Biologi sebagai bagian dari sains sudah seharusnya menekankan keterlibatan siswa secara langsung dalam pembelajarannya melalui pengalaman belajar yang memuat keterampilan proses sains (Subali, 2010). Hal tersebut dapat dioptimalkan melalui pembelajaran yang memuat metode ilmiah (scientific process). Pembelajaran saat ini masih berpusat pada guru (teacher centered) sehingga peserta didik pasif saat proses pembelajaran. Sedangkan dalam kurikulum 2013 mengehendaki pembelajaran berpusat pada peserta didik (Student centered) dengan pendekatan ilimah yang mencakup tiga aspek yaitu, sikap, pengetahuan dan keterampilan.

Keterampilan proses sains merupakan keterampilan yang melibatkan semua kemampuan yang dimiliki peserta didik, diantaranya keterampilan intelektual, sosial dan manual yang didasarkan pada metode ilmiah yang dapat dibangun oleh peserta didik itu sendiri. Untuk memunculkan keterampilan tersebut dibutuhkan pembelajaran bermakna yang melibatkan metode ilmiah yakni, 5M yaitu mengamati, menanya, menalar, mencoba dan mengaplikasikan. Maka dari itu keterampilan proses sains menjadi sangat penting untuk dimiliki peserta didik dalam pembelajaran sains.

Kemampuan memahami konsep merupakan salah satu syarat dalam keberhasilan suatu pembelajaran, sehingga peserta didik dapat menyelesaikan permasalahan dalam kehidupan sehari-hari. Penguasaan konsep penting menjadi dasar keterampilan proses sains, karena dalam menyelesaikan suatu permasalahan dan menumbuhkan keterampilan membutuhkan konsep dasar. Melalui pengalaman belajar yang didasari oleh konsep, peserta didik dapat melatih keterampilan proses sains dan membangun pengetahuan (kontruktivis). Penguasaan konsep merupakan dasar untuk membangun konsep lainnya, sehingga peserta didik diharapkan dapat mengonstruk sendiri pengetahuannya. Pada hakikatnya program pembelajaran bertujuan tidak hanya memahami dan menguasai apa dan bagaimana sesuatu terjadi, tetapi juga memberikan pemahaman dan penguasaan tentang "mengapa hal ini terjadi?". Pada kenyataan dilapangan peserta didik hanya mengacu pada proses mengingat dan menghafal konsep tanpa memahami maknanya. Berpijak pada

\section{Robiatul, dkk}


permasalahan tersebut, maka pembelajaran scientific process sangat penting untuk diterapkan (Wena, 2011).

Hasil observasi di salah satu Sekolah Menengah Pertama Negeri Kota Sukbumi didapatkan bahwa dalam proses pembelajaran, keterampilan proses sains masih belum dilatihkan. Guru masih mengandalkan Lembar Kerja Siswa (LKS) yang ada di dalam buku pegangan guru, dan pembelajaran masih lebih berpusat pada guru

Maka dari itu, menyadari pentingnya keterampilan proses sains dalam menunjang proses pembelajaran yang dapat merangsang peserta didik agar dapat berperan aktif di kelas dan menumbuhkan sikap ingin tahu dalam proses pembelajaran. Sehingga peneliti tertarik untuk mengetahui profil keterampilan proses sains siswa kelas VII SMPN Kota Sukabumi pada materi ekosistem semester genap tahun ajaran 2019/2020.

\section{METODE PENELITIAN}

Penelitian ini menggunakan metode deskriptif dan pendekatan kualitatif. Tujuan dari penggunaan metode deskriptif menurut Ali (2010) adalah untuk mendeskrifsikan kebenaran fenomena berdasarkan data empiris sebagai jawaban terhadap masalah yang diteliti dalam penelitian yang dilakukan. Populasi pada penelitian ini adalah siswa kelas VII SMPN Kota Sukabumi sebanyak 30 siswa. Sampel diambil dengan menggunakan teknik purposive sampling yakni dilakukan dengan cara mengambil subjek bukan didasarkan atas strata, random atau daerah tetapi didasarkan atas adanya tujuan tertentu. Penelitian ini dilaksanakan pada bulan april 2020 diminggu ke-4.

Pengumpulan data dilakukan dengan menggunakan tes tertulis dalam bentuk pertanyaan soal pilihan ganda keterampilan proses sains yang berjumlah 20 soal pertanyaan dengan reliabilitas 0,78 standar deviasi standar deviasi 3,20 dan korelasi 0,63 menggunakan 10 indikator keterampilan proses sains. Indikator tersebut menurut Rustaman (2005) yang meliputi, mengobservasi, mengklasifikasi, menginterpretasi, memprediksi, mengajukan pertanyaan, menyusun hipotesis, merancang percobaan, menggunakan alat dan bahan, menerapkan konsep serta mengkomunikasikan. Adapun indeks KPS menurut freamwork Purwanto (2002) dapat dilihat pada table 1.

Table 1. Klasifikasi Indeks Persentase KPS freamwork Purwanto (2002)

\begin{tabular}{cc} 
Tingkat Penguasaan & Prediksi \\
\hline $86-100 \%$ & Sangat Baik \\
\hline $76-85 \%$ & Baik \\
\hline $60-75 \%$ & Cukup \\
\hline $55-59 \%$ & Kurang \\
\hline$\leq 54 \%$ & Kurang Sekali
\end{tabular}




\section{HASIL DAN PEMBAHASAN}

Keterampilan proses sains merupakan keseluruhan keterampilan ilmiah terarah yang digunakan untuk menemukan fakta, konsep, atau teori. Kemampuan ini akan membuat peserta didik memiliki pengalaman langsung terhadap suatu fenomena biologi di sekitarnya dan mengubah persepsi terhadap hal-hal penting. Keterampilan proses melibatkan keterampilan-keterampilan kognitif atauintelektual, manual, dan sosial. Keterampilan kognitif atau intelektual terlibat karenadengan melakukan keterampilan proses, siswa menggunakan pikirannya. Keterampilan manual jelas terlibat dalam keterampilan proses karena mungkinmereka melibatkan penggunaan alat dan bahan, pengukuran, penyusunanatauperakitan alat. Dengan keterampilan sosial dimaksudkan bahwa mereka berinteraksidengan sesamanya dalam melaksanakan kegiatan belajar mengajar denganketerampilan proses, misalnya mendiskusikan hasil pengamatan (Rustaman, 2005).

Berdasarkan pandangan IPA sebagai proses, dalam pembelajaran IPA saat ini digunakan keterampilan proses. Keterampilan proses ains (KPS) dapat diartikan sebagai wawasan atau anutan pengembangan keterampilan keterampilan intelektual, sosial, dan fisik yang bersumber dari kemampuan-kemampuan mendasar yang pada prinsipnya ialah ada di dalam diri peserta didik. yang memberi kesempatan kepada siswa agar dapat menemukan fakta, membangun konsepkonsep, melalui kegiatan dan atau pengalaman-pengalaman seperti ilmuwan (Muh,\& Liliasari, 2014).

Indikator yang diamati dari Keterampilan Proses Sains ini yaitu menurut Rustaman (2005) terdapat 10 indikator yakni diantaranya mengobservasi, mengklasifikasikan, menginterpretasi, memprediksi, mengajukan pertanyaan, menyusun hipotesis, merancang percobaan, menggunakan alat dan bahan, menerapkan konsep serta mengkomunikasikan. Observasi ini dilakukan dengan menggunakan tes soal pilihan ganda keterampilan proses sains pada materi ekosistem. Data hasil observasi keterampilan proses sains kelas VII SMPN berjumlah 30 siswa. Adapun hasil observasi dari kelas VII SMPN Kota Sukabumi dapat dilihat pada table 2 .

Tabel 2. Hasil Keterampilan Proses Sains kelas VII SMPN Negeri Kota Sukabumi

\begin{tabular}{llll} 
No & Indikator Kps & $\mathbf{( \% )}$ & Kategori \\
\hline 1 & Mengobservasi & $40,51 \%$ & Kurang Sekali \\
2 & Mengklasifikasikan & $24,33 \%$ & Kurang Sekali \\
3 & Menginterpretasi & $30,00 \%$ & Kurang Sekali \\
4 & Memprediksi & $54,32 \%$ & Kurang \\
5 & Mengajukan Pertanyaan & $45,22 \%$ & Kurang Sekali \\
6 & Berhipotesis & $57,30 \%$ & Kurang \\
7 & Merancang Percobaan & $20,42 \%$ & Kurang Sekali \\
8 & Menggunakan Alat dan Bahan & $64,75 \%$ & Cukup \\
9 & Menerapkan Konsep & $23,45 \%$ & Kurang Sekali \\
10 & Mengkomunikasikan & $55,00 \%$ & Kurang \\
\hline Rata-rata & $38,83 \%$ & Kurang Sekali
\end{tabular}


Dari tabel data diatas hasil keterampilan proses sains dapat dikatakan masih dalam kategori kurang. Adapun rincian data pada setiap indikator keterampilan proses sains yaitu, indikator memprediksi sebesar $54,32 \%$, mengkomunikasikan sebesar 55,00\% dan berhipotesis 57,30\% menerapkan konsep 23,45\% termasuk kedalam kategori kurang. Kemudian yang termasuk kedalam kategori kurang sekali meliputi indikator mengobservasi sebesar 40,51\%, mengklasifikasikan sebesar $24,33 \%$, merancang percobaan sebesar 20,42\% dan menginterpretasi sebesar $30,00 \%$. Sedangkan indikator yang dikategorikan kedalam cukup hanya satu yaitu menggunakan alat dan bahan $64,75 \%$

Menurut Purwanto (2002) keterampilan proses sains tergolong rendah apabila kurang dari 54\%. tiga aspek yang tergolong kurang sekali yaitu mengobservasi, mengklasifikasikan, merancang percobaan dan menginepretasi. Penyebab rendahnya keterampilan proses sains siswa kelas VII SMPN Negeri Kota Sukabumi yaitu pelaksanaan kegiatan praktikum sangat jarang dilakukan pada materi IPA yang membutuhkan untuk belajar secara praktik atau terlibat kedalam pengalaman secara langsung. Siswa hanya mematuhi instruksi yang diberikan guru, dengan LKS yang berbasis teks book sehingga siswa tidak terbiasa untuk mengklasifikasikan sesuatu, membuat hipotesis dan merencanakan percobaan. kemudian model pembelajaran yang diterapkan oleh guru masih belum memfasilitasi peserta didik untuk menemukan sebuah konsep dengan melakukan proses kerja ilmiah.

Berdasarkan analisis data hasil observasi, dapat disimpulkan bahwa masalah dari rendahnya keterampilan proses sains disebabkan beberapa faktor yaitu, sarana dan prasarana yang kurang, seperti laboratorium, buku dan lain sebagainya, kemudian dikarena model, strategi dan pendekatan pembelajaran masih belum mengeksplor kegiatan pemebelajaran yang dapat melatih keterampilan proses sains peserta didik secara optimal, sehingga diperlukan penerapan model, strategi dan pendekatan pembelajaran yang mampu meningkatkan keterampilan proses sains siswa.

Model pembelajaran inkuiri merupakan salah satu model pembelajaran yang berperan penting dalam membangun keaktifan belajar siswa yang mengahasilkan keterampilan-keterampilan dalam sains dasar seperti keterampilan berinkuiri (Setiono et al., 2017). Secara umum inkuiri dapat dilakukan melalui beberapa tahapan mulai dari merumuskan masalah, mengajukan masalah, mengajukan hipotesis, mengumpulkan data, menguji data berdasarkan data yang ditemukan dan membuat kesimpulan (Sanjaya, 2008). Model ini diharapkan siswa menjadi ilmuan atau dalam kata lain dalam pembelajarannya siswa diajarkan untuk menemukan jawaban dari yang dibahas dengan melakukan percobaan layaknya ilmuan/peneliti masalah dengan bimbingan dari guru (Setiono, et al., 2019).

Trianto (2009) menyatakan bahwa inkuiri hanya mengembangkan kemampuan intelektual, tetapi seluruh potensi yang ada, termasuk pengembangan emosional dan keterampilan. Penerapan model guided inquiry membutuhkan keaktifan peserta didik yang menumbuhkan sikap ilmiah dalam pembelajaran. Pembelajaran inkuiri merupakan proses yang bermula dari merumuskan masalah, 
membuat hipotesis, mengumpulkan data, menganalisis data, dan membuat kesimpulan. Dalam hal ini inquiry dapat melatih keterampilan proses sains peserta didik melalui pengalaman belajar.

Keterampilan proses sains dapat membantu memudahkan peserta didik dalam menyelesaikan masalah yang dihadapi dalam pembelajaran. Pembelajaran dengan model guided inquiry dapat memudahkan peserta didik dalam memahami materi yang diberikan sehingga dapat meningkatkan pemahaman konsep peserta didik (Siska, dkk. 2015). Keterampilan proses sains dapat melibatkan semua kemampuan yang dimiliki peserta didik, diantaranya keterampilan intelektual, sosial dan manual yang didasarkan pada metode ilmiah yang dapat dibangun oleh peserta didik itu sendiri. Maka dari itu keterampilan proses sains menjadi sangat penting untuk dimiliki.

\section{KESIMPULAN}

Berdasarkan hasil observasi yang telah diperoleh maka dapat ditarik kesimpulan bahwa profil keterampilan proses sains siswa peserta didik kelas VII SMPN Kota Sukabumi pada tahun ajaran 2019/2020 masih dalam kategori kurang. Namun dari hasil tersebut, keterampilan proses sains masih bisa dilatihkan dan ditingkatkan melalui penggunaan model, strategi dan pendekatan pembelajaran yang mampu merangsang keterampilan proses sains peserta didik. Salah satu model pembelajaran yang disarankan yaitu model pembelajaran inkuiri.

\section{DAFTAR PUTAKA}

Ali, M. (2010). Metodologi dan aplikasi riset pendidikan. Bandung: Pustaka Cendikia Utama

Abungu, H,E., Okere, M.I.O., \& Wachanga, S.M. (2014). The Effect of Science Process Skills Teaching Approach on Secondary School Students' Achievement in Chemistry in Nyando District, Kenya. Journal of Educational and Social Research, 4(6): 359-372.

Joyce, B., Weil, M., \& Calhoun, E. (2009). Models of Teaching (Model-model Pengajaran).Yogyakarta: Pustaka Pelajar.

Purwanto. (2002). Evaluasi Hasil Belajar. Yogyakarta: Pustaka Pelajar.

Rustaman, dkk. (2005). Strategi belajar mengajar biologi. Malang: Universitas Negeri Malang.

Sanjaya, W. (2008). Pembelajaran Dalam Implementasi Kurikulum Berbasis Kompetensi. Jakarta: Prenata Media Group.

Setiono, Rustaman, N.Y., Rahmat, A., Anggraeni, S. (2017). Implementasi guided inquiry laboratorium pada praktikum anatomi tumbuhan. Jurnal Utile. 3, (2)195-201.

Setiono, N Y Rustaman, A Rahmat, \& S Anggraeni (2019). Student's Inquiry Skills and Learning Achievement in Plant Anatomy Practical Work Using OpenGuided Inquiry. IOP (Journal of Physic) 157. 
Subali, B. (2010). Bias Item Tes Keterampilan Proses Sains Pola Divergen dan Modifikasinya sebagai Tes Kreativitas. Jurnal Penelitian dan Evaluasi Pendidikan.14(2), 309-334.

Wena, M. (2011). Strategi Pembelajaran Inovatif Kontenporer. Jakarta: Bumi Aksara.

Muh. T.\& Liliasari. Keterampilan-Keterampilan Proses Sains dan Implementasinya dalam Pembelajaran IPA. (Makassar: Badan Penerbit Universitas Negeri Makassar, 2014), h.8.

Siska N. M., Parmin, dan Stephani D. P. (2015). Penerapan Model Guided Inquiry Terhadap Sikap IImiah dan Pemahaman Konsep Siswa pada Tema Ekosistem. Unnes Science Education Journal. 4(3).

Trianto.(2009).Mendesain Model Pembelajaran inovatif-progresif konsep, Landasan dan Implementasinya pada Kurikulum Tingkat Satuan Pendidikan (KTSP). Jakarta: Kencana Prenada Media Group. 